\title{
AMI Information System of Ganesha University of Education with Decision Support System
}

\author{
Kadek Bondan Noviada \\ PTI, UNDIKSHA \\ Singaraja, Bali
}

\author{
I Made Agus Wirawan \\ PTI, UNDIKSHA \\ Singaraja, Bali
}

\author{
I Made Gede Sunarya \\ PTI, UNDIKSHA \\ Singaraha, Bali
}

\begin{abstract}
AMI (Internal Quality Audit) is the program that exist at all of the University in Indonesia to control their quality. UNDIKSHA is one of many University in Indonesia which is implementing the AMI program. However, the AMI program in UNDIKSHA is was not implemented correctly because the implementation is still using manual system without decision support system. This study aims to: (1) implementing AMI (Audit Mutu Internal) Information System of Ganesha University of Education with Decision Support Systems. (2) To know the user response of AMI (Audit Mutu Internal) Information System of Ganesha University of Education with Decision Support System implementation..

The method that used in this research is research and development. AMI (Audit Mutu Internal) Information System of Ganesha University of Education with Decision Support System was developed with the waterfall model. Subjects were the expert of AMI suggested by UJM (Quality Assurance Unit) Ganesha University of Education. The data that collected are data of lecturers response to the development of implementing AMI (Audit Mutu Internal) Information System of Ganesha University of Education with Decision Support Systems by using the questionnaires.

The results of this research is the implementation of AMI (Audit Mutu Internal) Information System of Ganesha University of Education with Decision Support Systems. The results of the system test indicates that, this system can be run at the Ganesha University of Education. This system has been completely meet the functional requirements on the design of the system and allows overcoming the problems that described above
\end{abstract}

\section{Keywords}

Audit Mutu Internal, Unit Jaminan Mutu, Decision Support System, Simple Additive Weighting

\section{INTRODUCTION}

Indonesia is developing country that always improving quality in all of the country sector. One of the sector that become a focus to be improved is education. The quality of education in Indonesia is not well right now, this is why that Indonesia need to focus on improving an education quality[1].

To improve their quality in education, Indonesia makes one organization called BAN PT (organization under government who keep the quality of education in college classes). This organization have many program to keep the quality of the university in Indonesia . One of many BAN-PT program is called AMI (Audit Mutu Internal)/(Internal Quality Control). This is the complex program of auditing the university to keep and improve their quality. AMI is the university quality control program that runs two time a year. To run AMI, the university need to do the standard procedure and they have to make one unit to handle this program.
UNDIKSHA is one of many University in Indonesia which is implementing the AMI program. However, the AMI program in Undiksha was not implemented correctly because the implementation is still using manual system without decision support system. In order to implemets AMI program, Undiksha makes one organization called UJM (Unit Jaminan Mutu)/(Quality Control Unit, the Unit that created to handle this program). To run AMI, UJM need to do the standard procedure according to BAN-PT standard, these procedure are[2],

a. Recruiting AMI auditor to audit all of department in the university.

b. Train the auditor to make them understand about what they have to do to execute AMI program.

c. Make an Instrument including the questionnaire about the department quality. (the instrument must contains BAN-PT standard instrument)

d. Distribute the questionnaire to all of the department in the university so they will be able to answer the questionnaire.

e. All of the auditor go to all of the department in university according to the task and schedule management to the department quality.

f. The auditor bring the form of control to give the value of decision to each department in university.

g. After several day, the auditor form will be collected by UJM to make a decision score of what the accreditation type of the department.

h. UJM calculate manually all of the department scores that given by auditor by hundreds of form to make a final score decision.

i. When the final score has been released, the department have to take their score and start correcting their weakness.

j. The UJM have to release the AMI yearly report.

The problem that analyzed based on these steps are,

a. This program runs manually, so in order to make all of this system completely runs, UJM is wasting more time.

b. This program was not supported by WEB Information system so it wasted more paper and more time to calculate the value scores manually.

c. Auditor and department will be so busy in order to complete their task because they are not helped by pocket technology, even though there are a lot of pocket technology that can be applied to help auditor to do their job. 
d. There is no decision support system used in order to get the value of department scores in AMI Implementation.

Based on the problem that described above, UJM need the web system to deal with this problem. That web system need a special database to save the AMI data, so the much paper is not long be necessary. That system must to have a decision support system to define a specific scores of department faster. The system must include by pocket technology of android so much of auditor forms are no longer needed[1].

Base on the solution, researcher recommends one system to solve all of this problem. The system is AMI Information System of Ganesha University of Education with Decision Support System. Hopley this system can be the answer of all of the problem of AMI program implementation in Indonesia.

\section{AMI (AUDIT MUTU INTERNAL)/(INTERNAL QUALITY CONTROL)}

AMI (Internal Quality Audit) is a system that used by UJM to control the performance of lectures and the quality department through a comprehensive instrument designed by the UJM of UNDIKSHA (Ganesha University of Education)[2]. UNDIKSHA implement AMI through UJM UNDIKSHA systematically and comprehensively with a view to evaluating the performance of faculty and department in UNDIKSHA. AMI was first implemented in 2010 which carried out only one part of the Tri Dharma Perguran Tinggi knowlegdgements, it is education. Participation in the majors that year only 24 departments in UNDIKSHA. Over the years, the department that participate with this program reached 32 department with a total of 36 accommodation Auditor Expert. This development is shown in Table development department participation as follows.[7]

Table 1 The quantity of department participation in AMI for several years[7]

\begin{tabular}{|l|l|l|}
\hline Number & AMI & $\begin{array}{l}\text { Quantity of } \\
\text { Department }\end{array}$ \\
\hline 1 & AMI in 2010 & 24 \\
\hline 2 & AMI in 2011 & 31 \\
\hline 3 & AMI in 2012 & 31 \\
\hline 4 & AMI in 2013 & 32 \\
\hline 5 & AMI in 2014 & 32 \\
\hline
\end{tabular}

The design of AMI Academic activities aimed to collecting data systematically as follows :

1. Preparation of Audit Form

2. Submission Form to each Program

3. Prodi fill Form

4. recruitment of candidates auditor

5. Train the auditor
6. Assignment Auditior to audit

7. Auditing implemented

8. Reporting of results Audit

9. Calculating the result scores

10. distributing the AMI final score to the department.

To make a good of AMI implementation, UJM always formed a committee to create a working system into lebis systematic audit. Here is a scheme of UJM work in implementing the AMI program,

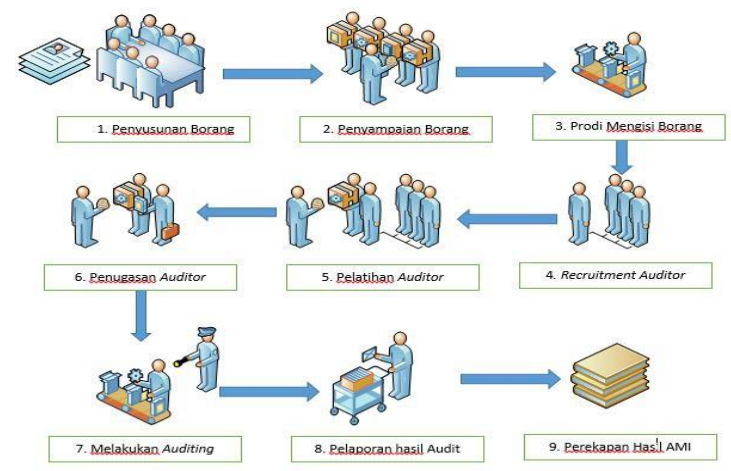

Picture 1 AMI Academic scheme program source: UJM, 2014)[4]

To make a good of AMI implementation focus on academic quality is required. The academic quality formed by the auditor quality who do as an auditor who implements AMI program which created to control the quality of the university[7].

\section{SIMPLE ADDITIVE WEIGHTING}

Simple Additive weighting method (SAW) or also known by the term weighted summation method. The basic concept is to rating the performance of each alternative on all attributes (Fishburn, 1967). SAW method requires a process of normalizing the decision matrix $(\mathrm{X})$ to a scale which can be compared with all of the rating and alternatives. This method is the method that most well-known and most widely used in situations of Multiple Attribute Decision Making (MADM)[2]. MADM is a method that used to find the optimal alternative of a number of alternatives to certain criteria. SAW method requires the decision maker determines the weights for each attribute. The total score for the alternative is obtained by summing over the multiplication of rating (which can be compared cross-attribute) and the weight of each attribute. Rating of each attribute dimension should be free in the sense that has gone through the process of normalization at the previous matrix[2].

SAW method has very simple step solution, but does not reduce the weights of each criterion to making decisions. The steps of SAW are as folows:

a. Determine the criteria that will be used as a reference in the decision, namely $\mathrm{Ci}$.

b. Determine the suitability of rating at each alternative on each criterion.

c. Making decisions based on criteria matrix $(\mathrm{Ci})$, then normalizing the matrix based on the equations that are tailored to the type attribute (attribute or 
attributes benefit costs) in order to obtain the normalized matrix R.

d. The final result is the summation of the normalized $\mathrm{R}$ matrix multiplication with the weight vector in order to obtain the greatest value is selected as the best alternative (Ai).

Here is a settlement scheme of one problems decision with SAW method that begins with the processing criteria and weights, as well as the selection of treatment alternative with the highest value.

For the example this is some cases that use saw to get the highest score according to criteria and weighting.

A company will perform work on the 5 candidate recruitment of workers for the position of the machine operator. The position is currently free only 2 positions with recruitment criteria as follows :

- Work experience ( C1 )

- Education ( C2 )

- Age ( C3 )

While the cost of its criteria are as follows :

- Marital status ( C4 )

- Address ( C5 )

Criteria and Weighting

we fill weight value of an alternative to the criteria that described

Table 2 Performance Table

\begin{tabular}{|l|l|l|l|l|l|}
\hline & \multicolumn{5}{|l}{ Criteria } \\
\hline Employee & C1 & C2 & C3 & C4 & C5 \\
\hline A1 & 0,5 & 1 & 0,7 & 0,7 & 0,8 \\
\hline A2 & 0,8 & 0,7 & 1 & 0,5 & 1 \\
\hline A3 & 1 & 0,3 & 0,4 & 0,7 & 1 \\
\hline A4 & 0,2 & 1 & 0,5 & 0,9 & 0,7 \\
\hline A5 & 1 & 0,7 & 0,4 & 0,7 & 1 \\
\hline
\end{tabular}

The next step is to do the weighting of the obtained criteria

Table 3 Weighting Table

\begin{tabular}{|l|l|}
\hline Criteria & Weight \\
\hline C1 & 0,3 \\
\hline C2 & 0,2 \\
\hline C3 & 0,2 \\
\hline C4 & 0,15 \\
\hline C5 & 0,15 \\
\hline Total & 1 \\
\hline
\end{tabular}

The next step is to change weights and criteria in the form of a matrix

Table 4 Matrix weight

\begin{tabular}{|l|l|l|l|l|}
\hline 0,5 & 1 & 0,7 & 0,7 & 0,8 \\
\hline 0,8 & 0,7 & 1 & 0,5 & 1 \\
\hline 1 & 0,3 & 0,4 & 0,7 & 1 \\
\hline 0,2 & 1 & 0,5 & 0,9 & 0,7 \\
\hline 1 & 0,7 & 0,4 & 0,7 & 1 \\
\hline
\end{tabular}

The next step is to multiply the value of a decision table with the weight of each criterion

$$
\begin{aligned}
& \mathrm{A} 1=(0.5 * 0.3)+(1 * 0.2)+(0.7 * 0.2)+(0,714 * 0.15 \\
& +(0,875 * 0.15) \\
& \mathrm{A} 1=0.72835 \\
& \mathrm{~A} 2=(0.8 * 0.3)+(0.7 * 0.2)+(1 * 0.2)+(1 * 0.15)+( \\
& 0.7 * 0.15) \\
& \mathrm{A} 2=0.835 \\
& \mathrm{~A} 3=(1 * 0.3)+(0.3 * 0.2)+(0.4 * 0.2)+(0.714 * 0.15) \\
& +(0.7 * 0.15) \\
& \mathrm{A} 3=0.6521 \\
& \mathrm{~A} 4=(0.2 * 0.3)+(1 * 0.2)+(0.5 * 0.2)+(0.556 * 0.15) \\
& +(1 * 0.15) \\
& \mathrm{A} 4=0.5934 \\
& \mathrm{~A} 5=(1 * 0.3)+(0.7 * 0.2)+(0.4 * 0.2)+(0.714 * 0.15) \\
& +(0.7 * 0.15) \\
& \text { A5 }=0.7321
\end{aligned}
$$

From the comparison of the final value , the value obtained as follows .

$$
\begin{aligned}
& \mathrm{A} 1=0.72835 \\
& \mathrm{~A} 2=0.835 \\
& \mathrm{~A} 3=0.6521 \\
& \mathrm{~A} 4=0.5934 \\
& \mathrm{~A} 5=0.7321
\end{aligned}
$$

Then the alternative that has the highest value and is an alternative A2 can be selected with a value of 0.835 and alternative A5 with the value 0.7321 .

\section{ANDROID MOBILE}

Android is an operating system for Linux-based mobile devices that includes an operating system, middleware and applications. Android provides an open source platform for developers to create their applications freely ( Safaat , 2012: 1 ) [3].

Android is open and free ( Safaat , 2012) . Complete Platform means that the developers can do a comprehensive approach when they are developing Android platform. Open Source Platform means a licensed Open Source Android platform so that developers can develop their applications freely[3].

We use android platform to implement an android validator program. As we know, we have to make all of the websites that we create should have a responsive environment so we can access the website completely on mobile, but we need more than just a mobile based web for auditor to do their complex task.

\section{THE IMPLEMENTATION OF AMI IN WEB SYSTEM AND MOBILE ANDROID VALIDATOR WITH DECISION SUPPORT SYSTEM}

Based on the solution that described at the introduction section. Researcher have designed web system and its function to make AMI information system[4]. The system should have a several function and difference user with difference access type[5]. We can divide the system as WEB system and Android validator.

The WEB system must have the difference function based on the difference user access. The user that will use the website divide as, 
a. Administrator (User who initiate the instrument data on the system such as, instrument, auditor data and auditee data ) [6].

b. Auditee (Leader of department who fill the instrument form based on the department situation) [6].

c. Auditor (Lecture or UJM Staff who have an authorized to control what auditee have been filled on the instrument) [6].

The android system that we made is the application to validate the department data based on what they are filled on the instrument. This is the reason why the application that we made is named Android Validator. The user of android validator is only the auditor. They will use the application when they are doing their task as an auditor to control what the department have been filled into the instrument form.

As the complete system, this is the steps of how this system works.

1. The web system accessed by the administrator at first. The administrator will enter the password and NIDN (national cod for national lecture) to access the feature.

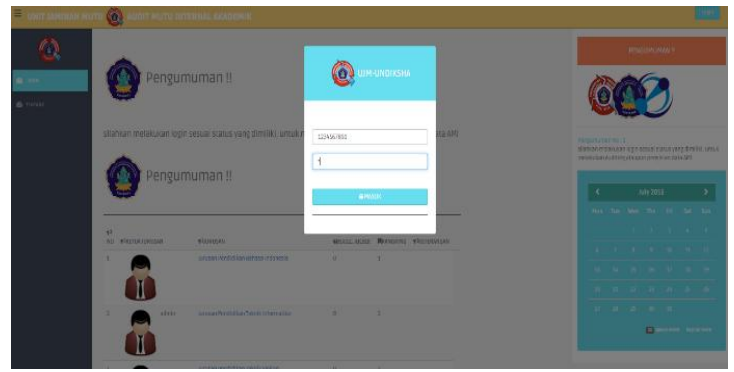

Picture 2 Display of Login

2. Administrator enter and modify the lectures data such as adding, editing, and dropping data.

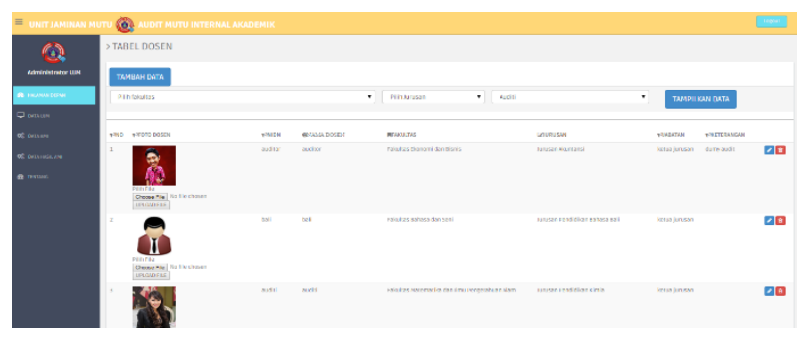

Picture 3 Display of User Data Modification

3. Administrator add the instruments data. This instrument will become a criteria that determine the final scores of department

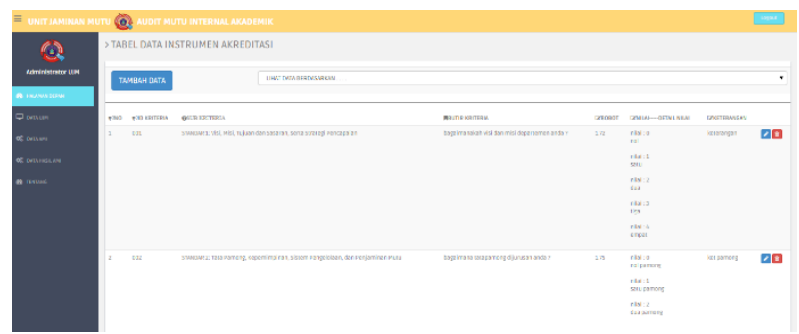

Picture 4 Display of Instrument Data Modification
4. Auditee login with difference password and NIDN so the system will recognize their status and their access type.

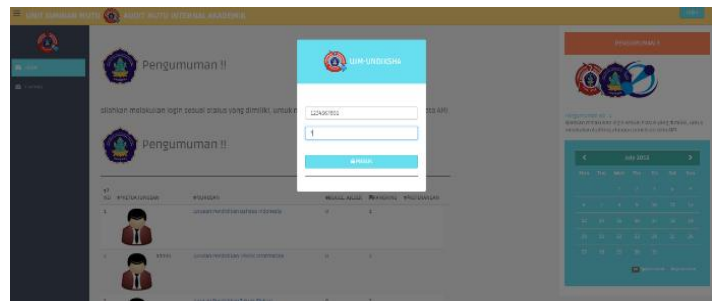

Picture 5 Display of Login Auditee

5. Auditee input the instrument answer according the instrument items that exist on the web.

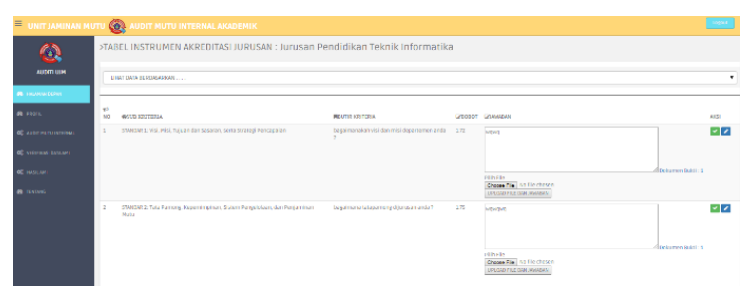

Picture 6 Display of Instrument Filling

6. Auditor Login with android application to access the feature and start the audit.

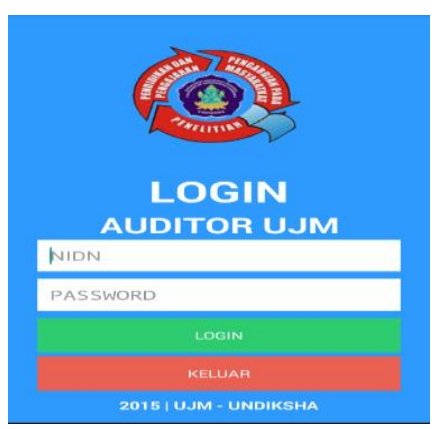

Picture 7 Display of Auditor Login

7. Auditor checking the auditee answer by using the android validator application.

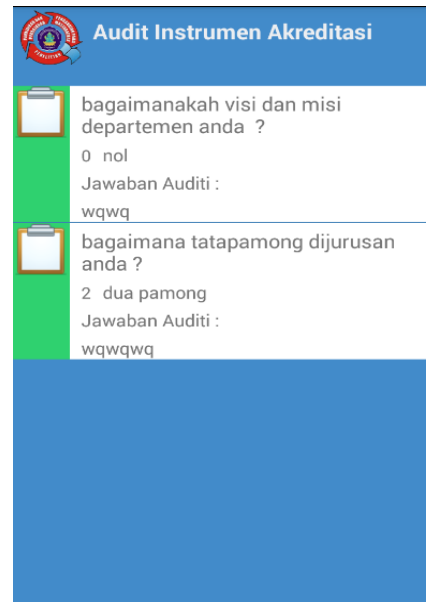

Picture 8 Display of Auditing Instrument 


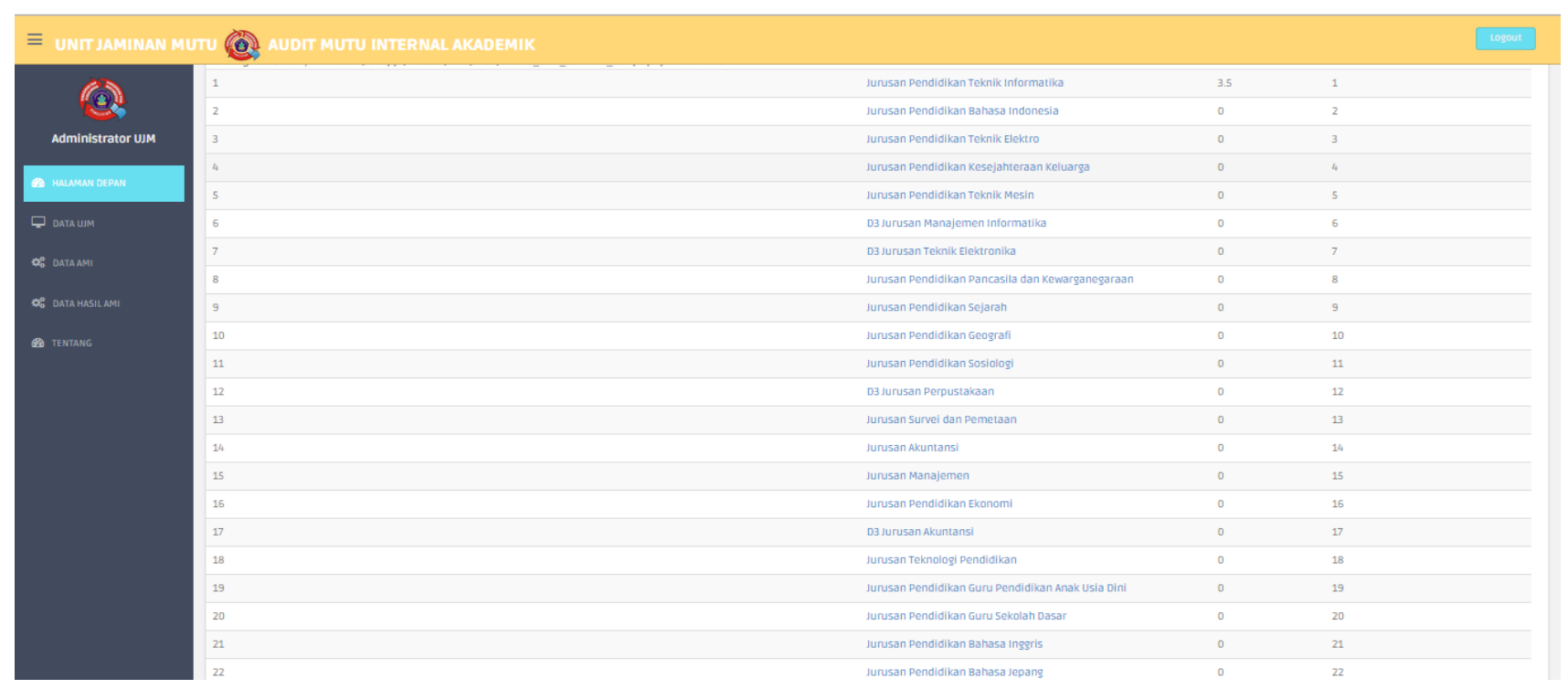

Picture 9 Display Rangk and AMI Result

8. The system will matically calculate the scores according to value of every criteria in

The system get the result from AMI instrument of weight calculation and the value that given by auditor when they are auditing the department.

Here is the calculation steps to get the result of AMI value.

In Undiksha there is many department:

a. Pendidikan Bahasa Indonesia

b. Pendidikan Bahasa Inggris

c. Pendidikan Bahasa Jepang

d. Pendidikan Bahasa Bali

e. Pendidikan Jasmani Kesehatan dan Rekreasi

f. Pendidikan Kepelatihan Olahraga

g. Ilmu Keolahragaan

h. Pendidikan IPA

i. Pendidikan Kimia

j. Pendidikan Matematika

k. Pendidikan IPA

1. Pendidikan Biologi

m. Pendidikan Teknik Informatika

n. Pendidikan Kesejahteraan Keluarga

o. Pendidikan Teknik Elektro

p. Pendidikan Pancasila

q. Pendidikan Sejarah

r. Pendidikan Guru Sekolah Dasar

s. Tekonologi Pendidikan

t. Pendidikan Anak Usia Dini

u. Akuntansi
In AMI there is many criteria :

Table 5 AMI criteria and weight

\begin{tabular}{|c|c|c|}
\hline No & Criteria & Weight \\
\hline 1 & $\begin{array}{l}\text { Persentase jumlah silabus yang dimiliki } \\
\text { terhadap total mata kuliah (mk) yang } \\
\text { diampu pada semester ganjil }\end{array}$ & 4 \\
\hline 2 & $\begin{array}{l}\text { Persentase jumlah SAP yang dimiliki } \\
\text { terhadap total mata kuliah yang diampu } \\
\text { pada semester ganjil }\end{array}$ & 4 \\
\hline 3 & $\begin{array}{l}\text { Persentase jumlah bahan ajar pendukung } \\
\text { (dapat berupa: buku ajar, buku penuntun } \\
\text { praktikum, atau diktat) yang dimiliki } \\
\text { terhadap total mata kuliah yang diampu } \\
\text { pada semester ganjil }\end{array}$ & 4 \\
\hline 4 & $\begin{array}{l}\text { Persentase jumlah rata-rata pertemuan } \\
\text { perkuliahan yang diampu pada semester } \\
\text { ganjil dibagi } 14 \text { (target pertemuan) }\end{array}$ & 4 \\
\hline 5 & $\begin{array}{l}\text { Persentase jumlah mata kuliah relevan } \\
\text { dengan bidang ilmu terhadap total mata } \\
\text { kuliah yang diampu pada semester ganjil }\end{array}$ & 4 \\
\hline 6 & $\begin{array}{l}\text { Persentase dosen aktif dengan kualifikasi } \\
\text { pendidikan terakhir S3 }(\mathrm{KD} 3=\text { jmlh dosen } \\
\text { aktif S3/total dosen aktif } \times 100 \%)\end{array}$ & 4 \\
\hline 7 & $\begin{array}{l}\text { Persentase dosen aktif dengan jabatan lektor } \\
\text { kepala (LK) atau guru besar (GB) yang } \\
\text { bidang keahliannya sesuai dengan } \\
\text { kompetensi PS (LK }=\text { jmlh dosen aktif } \\
(\text { LK+GB)/total dosen aktif x } 100 \%)\end{array}$ & 4 \\
\hline 8 & $\begin{array}{l}\text { Persentase dosen yang memiliki Sertifikat } \\
\text { Pendidik Profesional (Spp = jumlah dosen } \\
\text { yang memiliki Sertifikat Pendidik } \\
\text { Profesional/telah lulus serdos dibagi total } \\
\text { dosen tetap x } 100 \% \text { ) }\end{array}$ & 4 \\
\hline 9 & $\begin{array}{l}\text { Rasio mahasiswa terhadap dosen (RMD) } \\
\text { tetap yang bidang keahliannya sesuai } \\
\text { dengan bidang PS (RMD = total mahasiswa } \\
\text { aktif dibagi dosen tetap yang bidang } \\
\text { keahliannya sesuai dengan bidang PS x } \\
100 \% \text { ) }\end{array}$ & 4 \\
\hline 10 & Persentase mata kuliah (DMK) yang & 4 \\
\hline
\end{tabular}




\begin{tabular}{|l|l|l|}
\hline & $\begin{array}{l}\text { diampu oleh dosen yang sesuai keahliannya } \\
\text { (DMK = mata kuliah yang diampu oleh } \\
\text { dosen yang sesuai keahliannya dibagi total } \\
\text { mata kuliah yang diampu oleh dosen x } \\
100 \%)\end{array}$ & \\
\hline 11 & $\begin{array}{l}\text { Rata-rata persentase kehadiran dosen tetap } \\
\text { (PKDT) dalam perkuliahan (jumlah } \\
\text { kehadiran dibagi 14 x 100\%) }\end{array}$ & 4 \\
\hline 12 & $\begin{array}{l}\text { Ada pemanfaatan tenaga ahli dari luar } \\
\text { perguruan tinggi dengan tujuan untuk } \\
\text { pengayaan pengetahuan dan bukan untuk } \\
\text { mengisi kekurangan tenaga pengajar dan } \\
\text { tidak bekerja secara rutin }\end{array}$ & 4 \\
\hline 13 & $\begin{array}{l}\text { Rata-rata beban kerja (BK) mengajar dosen } \\
\text { pada semester ganjil (total beban SKS } \\
\text { semua dosen/total dosen) }\end{array}$ & 4 \\
\hline 14 & $\begin{array}{l}\text { Rata-rata beban kerja (BK) mengajar dosen } \\
\text { pada semester genap (total beban SKS } \\
\text { semua dosen/total dosen) }\end{array}$ & 4 \\
\hline 15 & $\begin{array}{l}\text { Ada bukti pelaporan hasil belajar } \\
\text { mahasiswa kepada orang tua/wali } \\
\text { mahasiswa }\end{array}$ & 3 \\
\hline 16 & $\begin{array}{l}\text { Ada bukti pengawasan terhadap proses } \\
\text { pembelajaran }\end{array}$ & 3 \\
\hline
\end{tabular}

In system we implement the code to transform this data into the matrix

Table 6 matrix AMI

\begin{tabular}{|l|l|l|l|l|}
\hline & Dep A & Dep B & Dep C & etc \\
\hline Crit 1 & 0,5 & 1 & 0,7 & 0,7 \\
\hline Crit 2 & 0,8 & 0,7 & 1 & 0,5 \\
\hline Crit 3 & 1 & 0,3 & 0,4 & 0,7 \\
\hline etc & 0,2 & 1 & 0,5 & 0,9 \\
\hline
\end{tabular}

The next step is to multiply the value of a decision table with the weight of each criterion

$$
\begin{aligned}
& \mathrm{A} 1=(0.5 * 0.3)+(1 * 0.2)+(0.7 * 0.2)+(0,714 * 0.15 \\
& )+(0,875 * 0.15) \\
& \mathrm{A} 1=0.72835 \\
& \mathrm{~A} 2=(0.8 * 0.3)+(0.7 * 0.2)+(1 * 0.2)+(1 * 0.15)+( \\
& 0.7 * 0.15) \\
& \mathrm{A} 2=0.835 \\
& \mathrm{~A} 3=(1 * 0.3)+(0.3 * 0.2)+(0.4 * 0.2)+(0.714 * 0.15) \\
& +(0.7 * 0.15) \\
& \mathrm{A} 3=0.6521 \\
& \mathrm{~A} 4=(0.2 * 0.3)+(1 * 0.2)+(0.5 * 0.2)+(0.556 * 0.15) \\
& +(1 * 0.15) \\
& \mathrm{A} 4=0.5934 \\
& \mathrm{~A} 5=(1 * 0.3)+(0.7 * 0.2)+(0.4 * 0.2)+(0.714 * 0.15) \\
& +(0.7 * 0.15)
\end{aligned}
$$$$
\text { A5 }=0.7321
$$

From the comparison of the final value, the value obtained as follows .
$\mathrm{A} 1=0.72835$
$\mathrm{A} 2=0.835$
$\mathrm{A} 3=0.6521$
$\mathrm{A} 4=0.5934$
$\mathrm{A} 5=0.7321$

Then the alternative that has the highest value and is an alternative A2 can be selected with a value of 0.835 and alternative A5 with the value 0.7321 .

\section{CONCLUSION AND SUGGESTION}

Conclusions obtained in the study of AMI Information System of Ganesha University of Education with Decision Support System are :

1. Based on the implementation which has been described previously we can conclude that using a WEB base information system in AMI could reduce the the problem that faced by UJM when implements AMI Manually.

2. Based on the implementation which has been described previously we can conclude that using a Mobile Android Technology in implements the android validator will help the auditor in order to do their job simpler than before.

3. Based on the implementation which has been described previously we can conclude that using a Decision Support System in AMI will help the system to generate the result faster and correctly.

Based on the results obtained in this study, it can be suggested several things:

1. For further research, it is necessary to make database more dynamically .

2. Like another Information system, this system need a socialization from expert to reduce human error in order to run the system correctly.

\section{ACKNOWLEDGMENTS}

Authors would like to thank for GANESHA University of Education and UJM has allowed and support for this research can be carried out smoothly.

\section{REFERENCES}

[1]. Pengembangan Humaniora. (2010). pengembangan humaniora sebagai sarana peningkatan mutu pendidikan tinggi, 15-18.

[2]. Efraim Turban, Aronson Jay E. (2001). Decision Support Sistem and Intelegent System. Prentiece Hall: Upper Saddle River, NJ.

[3]. Safaat, N. (2012). Mengungkap Source Code Android. Bandung: Informatika.

[4]. Joiyanto. (2005). Analisis dan Desain Sistem Informasi. Yogyakarta: ANDI.

[5]. Kadir, A. (2003). Pengenalan SIstem Informasi. Yogyakarta: ANDI.

[6]. Sonhadj, A. (2002). Laboratotrium Sebagai Basis Pendidikan Teknik di Perguruan Tinggi. Malang: Universitas Negeri Malang Pustaka.

[7]. UJM, U. (2014). Laporan AMI AKademik Tahun 2014. Singaraja: UJM UNDIKSHA. 